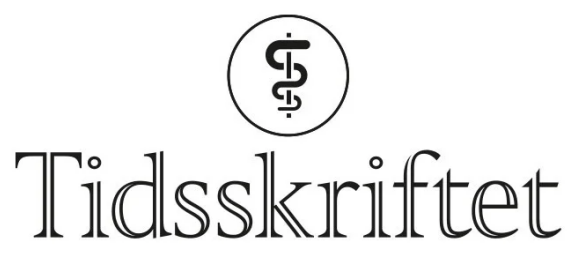

DEN NORSKE LEGEFORENING

\title{
Legeutdanning i en pandemitid
}

KOMMENTAR

\section{KNUT E.A. LUNDIN}

Knut E.A. Lundin (born 1958) is an associate professor and senior consultant at Oslo University Hospital.

The author has completed the ICMJE form and declares the following conflicts of interest: He has received fees from Abbvie, MSD, OrionPharma, Hospira, TakedaNycomed, Meda, Regeneron and GlaxoSmithKline.

HELGE RøSJØ

HILDE MYHREN

DAG KVALE

ELIN OLAUG ROSVOLD

Institutt for allmenn- og samfunnsmedisin Universitetet i Oslo

Mette Brekke, Cathrine Ebbing og Torben Wisborg fremfører velformulerte og gode bekymringer for «Legeutdanningen under en pandemi» (1) . Det er åpenbart at Covid-19 har medført belastninger på de aller fleste deler av samfunnet - også for legeutdanningen. Over natten måtte man utvikle digitale løsninger, og den ordinære studenthverdagen ble endret radikalt.

I artikkelen refereres det til at «I tillegg har sykehusene forståelig nok restriktive med å slippe til studentene på grunn av smitterisikoen» (2) .

Vi vil gjerne belyse dette med norske, lokale forhold fra Universitet i Oslo. De første månedene etter mars 2020 hersket det betydelig usikkerhet og studentene var ikke til stede på universitetssykehusene, mens praksis på lokalsykehusene ble opprettholdt i så godt som fullt omfang. Fra og med høsten 2020 har vi med svært få unntak opprettholdt den pasientnære undervisningen med journalopptak og kliniske smågrupper, både på Akershus universitetssykehus og Oslo universitetssykehus selv om disse sykehusene har hatt majoriteten av norske Covid-19-pasienter. Det er kun i spesielle situasjoner med ukontrollert smitte på sykehusenes sengeposter og i spesielt sårbare sykehusmiljøer at den kliniske studentundervisningen har vært avlyst. Ferdighetstrening og kurs har likeså vært 
oppretthold, om enn i nedskalert omfang og med strenge smittevern-tiltak. Den spontane hospiteringen, som vi oppfordrer studentene til, men som er vanskelig å få til i en travel studenthverdag, har det ikke vært åpning for.

Studentene selv har vist et stort ansvar knyttet til smittevern, noe som har gitt et lavt antall SARS-CoV-2-smittede medisinstudenter i Oslo. I de meget få tilfeller der våre studenter har vært smittet, og dette har medført karantene for øvrig helsepersonell, har dette vært møtt med en unik forståelse i sykehusmiljøene - «dette er den nye hverdagen».

Denne prioriteringen av utdanningen av leger har vært forankret på det høyeste nivå på Akershus universitetssykehus og Oslo universitetssykehus og gjennomført i løpende samråd med smittevern ved begge sykehusene. Samarbeidet har vært svært godt.

Ja, Covid-19 epidemien har vært og er en stor utfordring for oss alle. Vi står sannsynlig overfor en fjerde smittebølge, så det er all mulig grunn til høy beredskap videre. Men fra første stund ble det forutsatt og lagt planer for at studentenes læringsutbytte skulle beholdes på et tilstrekkelig nivå. Vår erfaring med uteksaminering av studenter som har hatt deler av sin legeutdanning i en pandemitid gjør at vi kan si oss enige i at «de vil bli like flinke leger på sikt». Faktisk tror vi de kanskje allerede kan være «like flinke».

\section{LITTERATUR}

1. Brekke M, Ebbing C, Wisborg T. Legeutdanning under en pandemi. Tidsskr Nor Legeforen 2021; 141. doi: 10.4045/tidsskr.21.0548. [CrossRef]

2. Brown A, Kassam A, Paget M et al. Exploring the global impact of the COVID-19 pandemic on medical education: an international cross-sectional study of medical learners. Can Med Educ J 2021; 12: 28-43. [PubMed]

Publisert: 6. september 2021. Tidsskr Nor Legeforen. DOI: 10.4045/tidsskr.21.0581

(C) Tidsskrift for Den norske legeforening 2023. Lastet ned fra tidsskriftet.no 26. april 2023. 